\title{
Optimizing interleukin-2 concentration, seeding density and bead-to-cell ratio of T- cell expansion for adoptive immunotherapy
}

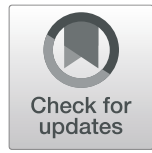

\author{
Sasan Ghaffari ${ }^{1,2}$, Monireh Torabi-Rahvar ${ }^{1,3}$, Sajjad Aghayan', Zahra Jabbarpour ${ }^{1}$, Kobra Moradzadeh',
} Azadeh Omidkhoda ${ }^{2 *}$ and Naser Ahmadbeigi $i^{*}$

\begin{abstract}
Background: The successful ex vivo expansion of T-cells in great numbers is the cornerstone of adoptive cell therapy. We aimed to achieve the most optimal T-cell expansion condition by comparing the expansion of T-cells at various seeding densities, IL-2 concentrations, and bead-to-cell ratios. we first expanded the peripheral blood mononuclear cells (PBMCs) of a healthy donor at a range of 20 to $500 \mathrm{IU} / \mathrm{mL} \mathrm{IL}-2$ concentrations, $125 \times 10^{3}$ to $1.5 \times$ $10^{6}$ cell/mL, and 1:10 to 10:1 B:C (Bead-to-cell) ratios and compared the results. We then expanded the PBMC of three healthy donors using the optimized conditions and examined the growth kinetics. On day 28, CD3, CD4, and CD8 expression of the cell populations were analyzed by flow cytometry.

Results: T-cells of the first donor showed greater expansion results in IL-2 concentrations higher than $50 \mathrm{IU} / \mathrm{mL}$ compared to $20 \mathrm{IU} / \mathrm{mL}(P=0.02)$. A seeding density of $250 \times 10^{3}$ cell/ $/ \mathrm{mL}$ was superior to higher or lower densities in expanding T-cells $(P=0.025)$. Also, we witnessed a direct correlation between the $\mathrm{B}: \mathrm{C}$ ratio and T-cell expansion, in which, in 5:1 and 10:1 B:C ratios T-cell significantly expanded more than lower B:C ratios. The results of PBMC expansions of three healthy donors were similar in growth kinetics. In the optimized condition, $96-98 \%$ of the lymphocyte population expressed CD3. While the majority of these cells expressed CD8, the mean expression of CD4 in the donors was 19.3, 16.5, and 20.4\%.
\end{abstract}

Conclusions: Our methodology demonstrates an optimized culture condition for the production of large quantities of polyclonal T-cells, which could be useful for future clinical and research studies.

Keywords: T-lymphocyte, Interleukin-2, Immunotherapy, Primary cell culture

\footnotetext{
* Correspondence: azadeh_omidkhoda@yahoo.com; n-

ahmadbeigi@tums.ac.ir

${ }^{2}$ Department of Hematology, School of Allied Medical Sciences, Tehran

University of Medical Sciences, Tehran, Iran

${ }^{1}$ Gene Therapy Research Center, Digestive Disease Research Institute, Tehran

University of Medical Sciences, Tehran, Iran

Full list of author information is available at the end of the article
}

(c) The Author(s). 2021 Open Access This article is licensed under a Creative Commons Attribution 4.0 International License, which permits use, sharing, adaptation, distribution and reproduction in any medium or format, as long as you give appropriate credit to the original author(s) and the source, provide a link to the Creative Commons licence, and indicate if changes were made. The images or other third party material in this article are included in the article's Creative Commons licence, unless indicated otherwise in a credit line to the material. If material is not included in the article's Creative Commons licence and your intended use is not permitted by statutory regulation or exceeds the permitted use, you will need to obtain permission directly from the copyright holder. To view a copy of this licence, visit http://creativecommons.org/licenses/by/4.0/ The Creative Commons Public Domain Dedication waiver (http://creativecommons.org/publicdomain/zero/1.0/) applies to the data made available in this article, unless otherwise stated in a credit line to the data. 


\section{Background}

Adoptive immunotherapy is currently an attractive approach to cancer treatment. It is defined as the application of expanded/manipulated immune cells adoptively transferred to a cancer patient to eliminate tumor cells, which can be used as a stand-alone treatment or in combination with traditional methods of radiotherapy, chemotherapy, and surgery $[1,2]$. One of the interesting modalities of adoptive immunotherapy is the adoptive transfer of $\mathrm{T}$ cells as the key player of anti-tumor immunity $[3,4]$. The three $\mathrm{T}$ cells of interest in this approach include tumor-infiltrating lymphocytes, $\mathrm{T}$ cell receptor T cells (TCR T cells), and chimeric antigen receptor $\mathrm{T}$ cells (CAR $\mathrm{T}$ cells), the latter of which has sparked greater attention among researchers and clinicians $[5,6]$. To deliver an effective adoptive $\mathrm{T}$ cell transfer, adequate expansion of cells is an essential step. This may not be an issue for hematological malignancies in which remission is not closely correlated with the number of $\mathrm{T}$ cells. However, $\mathrm{T}$ cell dose is particularly important in solid tumors where, in some cases, a few hundred billion $\mathrm{T}$ cells are required [7]. Accordingly, an efficient $\mathrm{T}$ cell expansion method to produce such numbers is a prerequisite of a successful ACT.

Most ACT protocols include isolating and in vitro expanding peripheral mononuclear cells (PBMCs). In order to produce polyclonal $\mathrm{T}$ cells, resting $\mathrm{T}$ cells must first be activated using a primary and secondary signal through CD3 and CD28 stimulation, respectively. T cell activation can be achieved using anti-CD3 antibodies (OKT3) and irradiated feeder cells; however, a more accessible strategy to activate $\mathrm{T}$ cells is simply adding small magnetic beads coated with anti-CD3/CD28 antibodies [8]. Beads are substitutes for antigen-presenting cells (APCs) and are one of three activation methods approved for clinical trials, which can be coated with any antibodies, are simple to use and remove, and can be used to separate any $\mathrm{T}$ cell subset [9]. The number of beads to cells, called bead-to-cell ratio, is a determinant of signal strength and consequently $\mathrm{T}$ cell expansion. While extremely high bead-to-cell ratio results in $\mathrm{T}$ cell exhaustion, too low ratios fail to activate $\mathrm{T}$ cells, both resulting in a suboptimal $\mathrm{T}$ cell expansion [10]. After activation, cells are seeded in culture plates. The number of cells seeded per $\mathrm{mL}$ is another determinant of effective cell expansion outcome, which has been previously shown in studies using osteoblasts, mesenchymal and adipose stem cells, and human umbilical vein endothelial cells [11-14]. For T cells, however, the optimized condition of successful expansion has not been clearly defined.

$\mathrm{T}$ cells require growth factors to expand, which are catered by the medium and serum. One growth factor is interleukin-2 (IL-2), which by binding to its receptor promotes the polyclonal expansion of $\mathrm{T}$ cells through binding to its cell surface receptor. Subsequently, the complex is quickly internalized, and then the $\alpha$ subunit (CD25) resurfaces to bind to IL-2. Hence, in an expansion course, it is pivotal to replenish IL-2 in the culture medium every 2-3 days [15]. Studies have used a wide range of 20 to $7200 \mathrm{IU} / \mathrm{mL}$ of IL-2 concentration for T cell expansion [16], though their difference in expansion efficacy is not clear.

Despite the improvement of $\mathrm{T}$ cell expansion protocols over the years, the optimum conditions for expansion are still elusive since there are many determinant factors. Hence, this study was designed to investigate the optimum condition for polyclonal $\mathrm{T}$ cell expansion with regards to three essential factors, i.e., IL-2 concentration, seeding density, and bead-to-cell $(\mathrm{B}: \mathrm{C})$ ratio.

\section{Results}

\section{Morphological observations}

Within the first $2 \mathrm{~h}$ of culture, cells started to form clusters of cells. This was evident in either low- and highdensity wells or low and high $\mathrm{B}: \mathrm{C}$ ratios; however, it was clear that the higher the density or the $\mathrm{B}: \mathrm{C}$ ratio was the more aggregates were observed. Since the cells' capacity to proliferate diminishes after 21 days and the beads are not replenished after day 0 , cells fail to form clusters in the final weeks. We also observed an increase in the size of mononuclear cells 3-4 days after the addition of beads (Fig. 1). This was seen in both the microscopic view and the forward and side scatter plots of $\mathrm{T}$ cells in flow cytometry.

\section{The effect of IL-2 on T cell expansion}

Five groups were assigned to determine the effect of varying IL-2 concentrations on $\mathrm{T}$ cell expansion. Cells supplemented with $20 \mathrm{IU} / \mathrm{mL}$ of IL-2 had the lowest expansion rate compared to other groups, which was statistically significant. When the IL-2 concentration increased to $50 \mathrm{IU} / \mathrm{mL}$, the expansion rate significantly increased in comparison to $20 \mathrm{IU} / \mathrm{mL}(p=0.02)$. Although a further increase in IL-2 concentration resulted in more expansion rate, on day 28 , there was no difference between cells cultivated in $500 \mathrm{IU} / \mathrm{mL}$ compared to $50(p=0.7), 100(p=0.8)$, and $200 \mathrm{IU} /$ $\mathrm{mL}(p=0.84)$ (Fig. 2).

\section{The effect of seeding density on $\mathrm{T}$ cell expansion}

$\mathrm{T}$ cells expanded in different cell densities showed diverse results. The cells seeded at $250 \times 10^{3} \mathrm{cell} / \mathrm{mL}$ and cells seeded at $1.5 \times 10^{6} \mathrm{cell} / \mathrm{mL}$ led to the highest and lowest expansion rates, respectively. An increase in the number of seeded cells from $62 \times 10^{3}$ cell $/ \mathrm{mL}$ to $250 \times$ $10^{3} \mathrm{cell} / \mathrm{mL}$ gradually improved expansion rate; however, further increases resulted in lower $\mathrm{T}$ cell expansions. On 


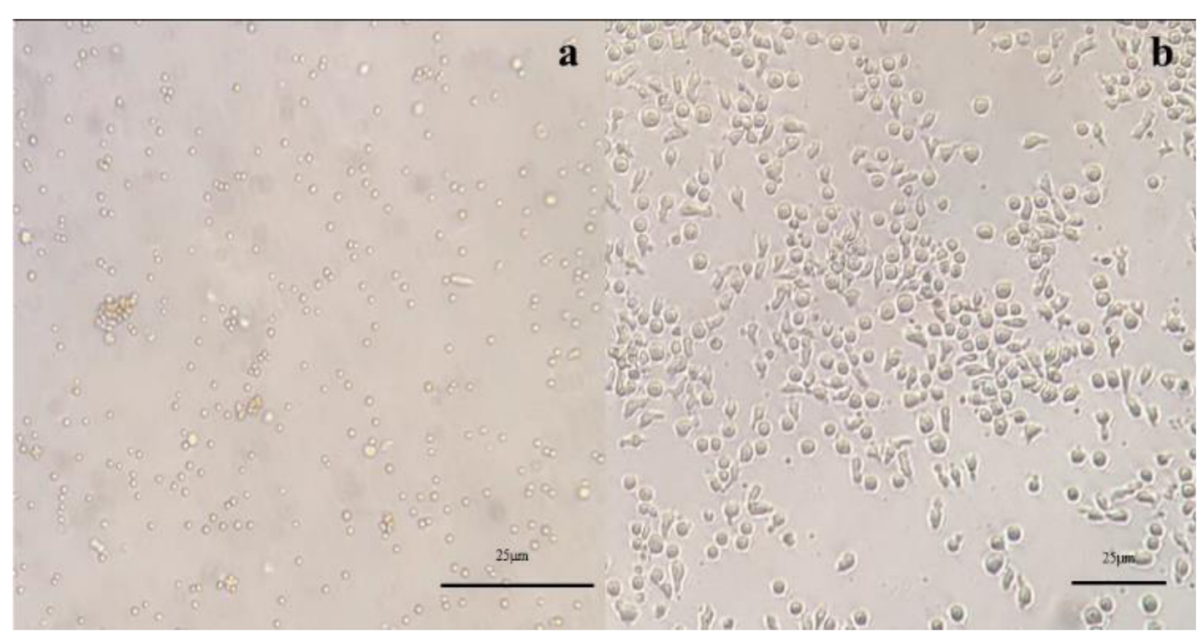

Fig. 1 The microscopic view of PBMCs on day 0 (a) and the expanded T cells on day 3 (b). After activation with anti-CD2/CD3/CD28 coated beads, cell sizes considerably increased

day 28 , cells seeded at $250 \times 10^{3} \mathrm{cell} / \mathrm{mL}$ resulted in significantly higher fold expansions compared with seeding densities of $62 \times 10^{3} \quad(p=0.007), 500 \times 10^{3} \quad(p=0.025)$, $1 \times 10^{6}(p=0.008)$, and $1.5 \times 10^{6}(p<0.0001)$ cell $/ \mathrm{mL}$. However, the difference was not significant compared to the seeding density of $125 \times 10^{3} \mathrm{cell} / \mathrm{mL}$ (Fig. 3).

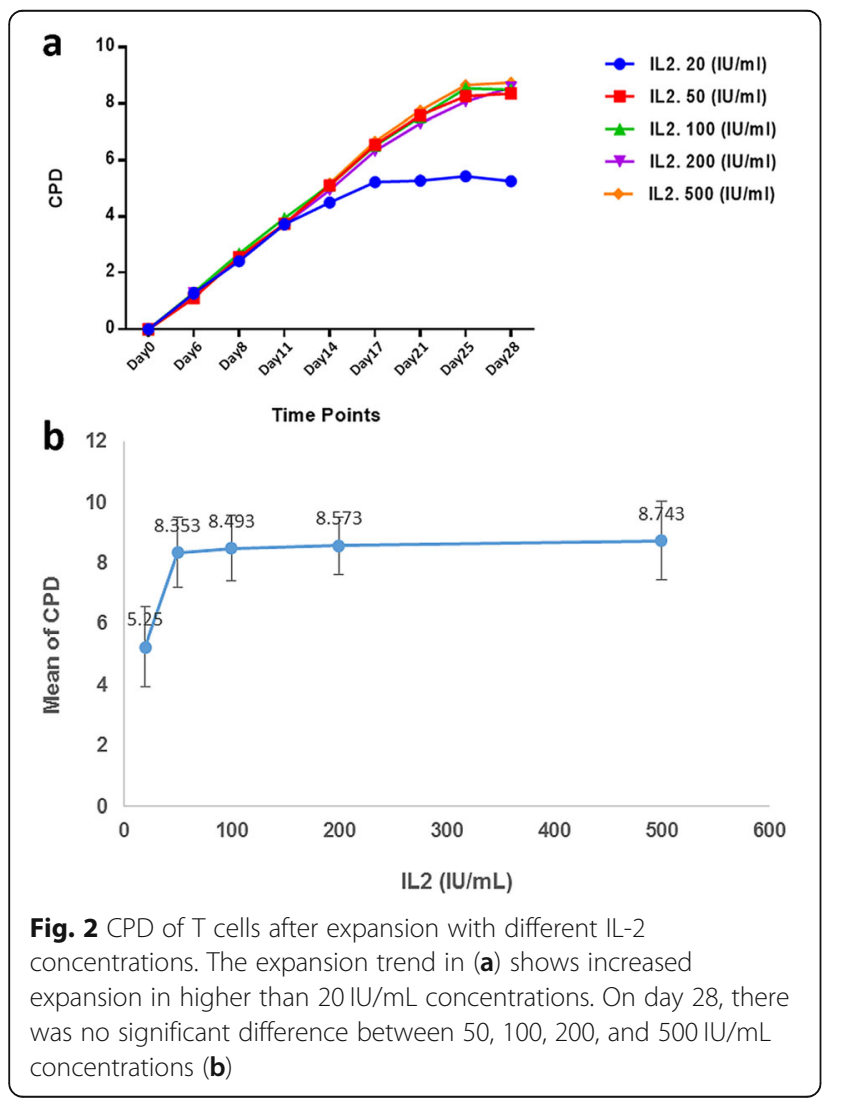

\section{The effect of bead-to-cell ratio on T cell expansion}

$\mathrm{T}$ cell expansion showed a direct correlation to the $\mathrm{B}: \mathrm{C}$ ratio. Therefore, the 10:1 $\mathrm{B}: \mathrm{C}$ ratio and $1: 10 \mathrm{~B}: \mathrm{C}$ ratio resulted in the highest and lowest fold expansions at the ninth time point. On day 28, the differences between fold expansions of $1: 10$ and 1:5 $(p=0.9), 1: 5$ and $1: 2$ $(p=0.9), 1: 2$ and $1: 1 \quad(p=0.9), 1: 1$ and $2: 1 \quad(p=0.95)$ groups were not significant. The cells stimulated with a 5:1 B:C ratio resulted in significantly more fold expansions compared with those stimulated with 2:1 $(p<$

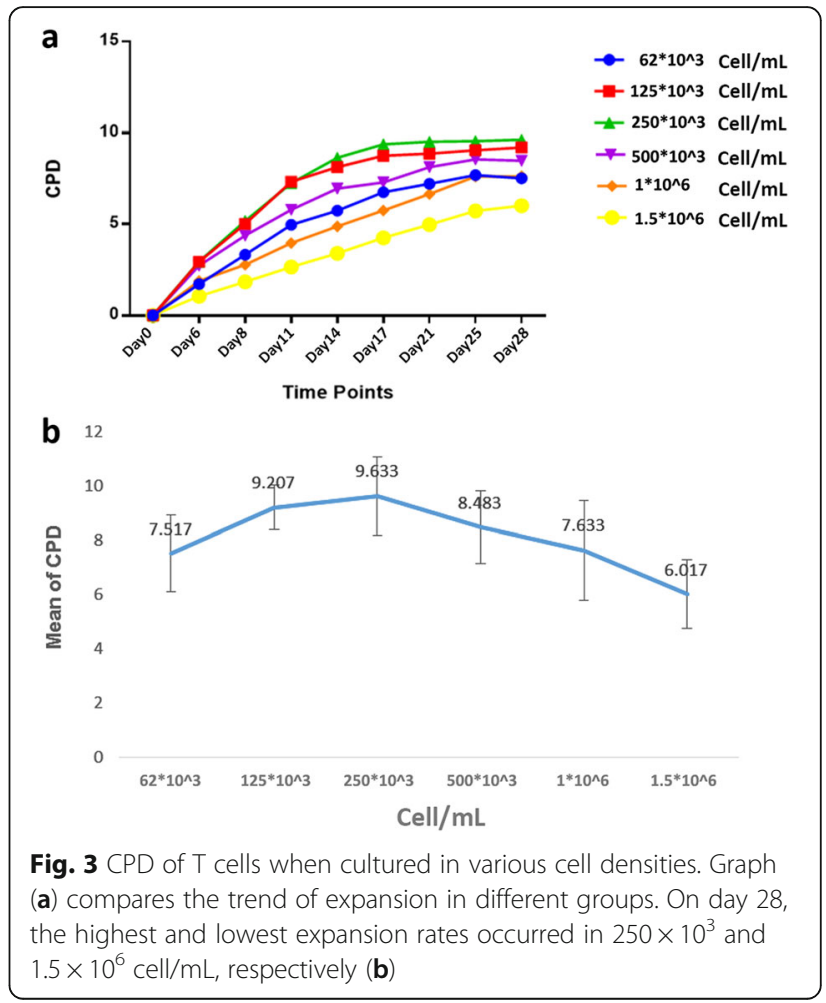




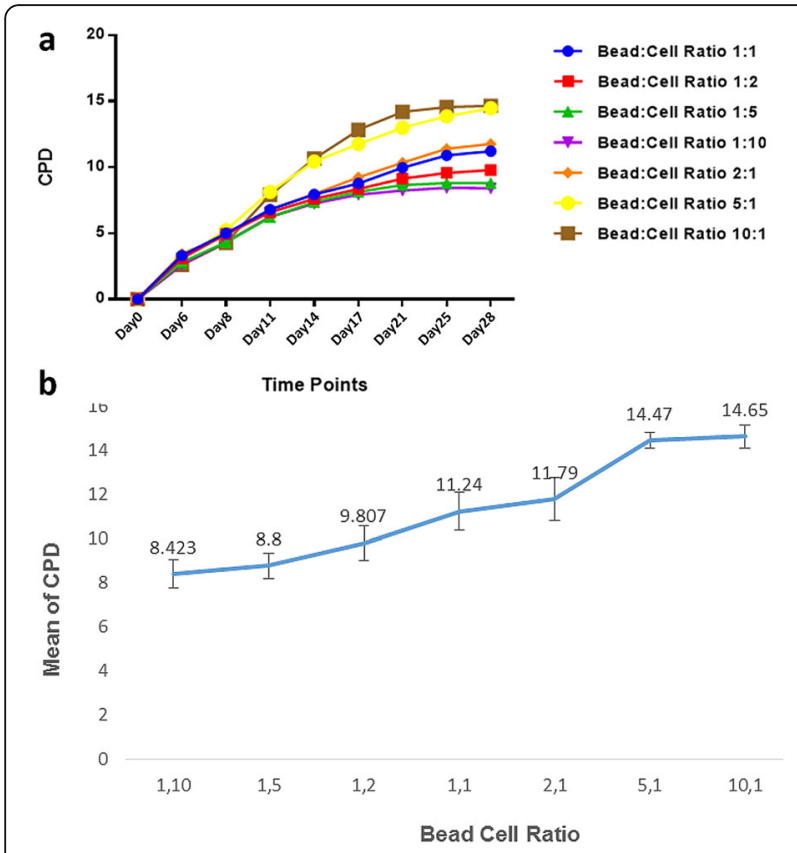

Fig. 4 CPD results of $T$ cells in various $B: C$ ratio groups. Over the culture period, the highest $\mathrm{B}: \mathrm{C}$ ratios generated the best expansion results (a). On day 28, a direct correlation between the number of beads and the expansion potential was seen $(\mathbf{b})$

0.0001). Stimulation with a 10:1 B:C ratio provided no significantly higher expansion rate than stimulation with 5:1 ( $p=0.087)$ (Fig. 4).

\section{Comparison of expansion rates in three donors}

In order to determine the reproducibility of results, the PBMCs of three donors in the condition with the highest yield of expansion plus one level higher and one level lower as per each determinant factor were cultured, and their results were compared with each other. When comparing IL-2 concentrations, $20 \mathrm{IU} / \mathrm{mL}$ IL-2 was found to be the least potent concentration for $\mathrm{T}$ cell expansion in all three donors (Fig. 5a, b). In donors 1 and 3, $100 \mathrm{IU} / \mathrm{mL}$ IL-2 expanded more $\mathrm{T}$ cells compared to $50 \mathrm{IU} / \mathrm{mL} \mathrm{IL}-2$, and conversely, $50 \mathrm{IU} / \mathrm{mL}$ showed slightly more expansion potential than $100 \mathrm{IU} / \mathrm{mL}$ in donor 2, but none of these differences were statistically significant. Comparing the $\mathrm{T}$ cell expansions of the three donors according to seeding densities of $125 \times 10^{3}$, $250 \times 10^{3}$, and $500 \times 10^{3} \mathrm{cell} / \mathrm{mL}, 250 \times 10^{3}$ cells $/ \mathrm{mL}$ seeding resulted in higher expansion rates $(p<0.0001)$ (Fig. $5 c, d)$. Finally, expansions of PBMC of three donors using 2:1, 5:1, and 10:1 B:C ratio showed that 2:1 ratio led to the lowest expansion rate and there was no difference between 5:1 and 10:1 ratio in the donors (Fig. 5e, f).

\section{Immunophenotyping results}

Immunophenotypic analysis showed the presence of 56$57 \% \mathrm{CD}^{+}$cells in the PBMCs prior to expansion at day
0 which, after 28 days of expansion in the optimum condition, this number increased to approximately $96 \%$ in all donors (Table 1 ). Moreover, the rate of $\mathrm{CD} 3 / \mathrm{CD}^{+}$ cells decreased from about $27 \%$ at day 0 to $16 \%$ at day 28 , and the majority of cells in the final time-point were $\mathrm{CD} 3 / \mathrm{CD}^{+}$.

\section{Discussion}

T-cells have a pivotal role in cellular immunity against tumor cells. One effective approach to cancer treatment would be a method for the isolation and ex vivo expansion of $\mathrm{T}$ cells. This requires optimized and highly efficient expansion protocols. To this end, isolated T-cells are first activated and then expanded in a well-defined condition to achieve a great number of cells. However, like many other cells, polyclonal $\mathrm{T}$ cell expansion lacks a unanimous efficient protocol [17]. In this study, we tried to optimize the expansion of polyclonal $\mathrm{T}$ cells in terms of three important determinants in the expansion of $\mathrm{T}$ cells: B:C ratio, IL-2 concentrations, and initial seeding density. We found that cultures in the condition of $250 \times 10^{3}$ cells $/ \mathrm{mL}$ seeding density in a 24 -well plate activated with 5:1 B:C ratio and $50 \mathrm{IU} / \mathrm{mL}$ IL-2 supplementation provide the most optimal $\mathrm{T}$ cell expansion.

IL-2 is a potent cytokine that drives both T cell expansion and differentiation from naive phenotype to stem cell memory $\mathrm{T}$ cells $\left(\mathrm{T}_{\mathrm{SCM}}\right)$, central memory $\mathrm{T}$ cells $\left(\mathrm{T}_{\mathrm{CM}}\right)$, effector memory $\mathrm{T}$ cells $\left(\mathrm{T}_{\mathrm{EM}}\right)$, and finally terminally differentiated effector $\mathrm{T}$ cells $\left(\mathrm{T}_{\mathrm{Eff}}\right)$. $\mathrm{T}_{\mathrm{Eff}}$ exhibit higher cytotoxic function and homing to peripheral tissues, while $\mathrm{T}_{\mathrm{SCM}}$ show less senescence and great selfrenewal and persistence [18]. Using other $y$-chain cytokines such as IL-7 and IL-15 have been proposed to augment $\mathrm{T}$ cell expansion and decrease differentiation. Although IL-7/IL-15-treated polyclonal T cells have less differentiation and more anti-tumor efficiency, they either show no significant T cell [19] expansion advantage or a small $\mathrm{T}$ cell [20] and CAR T cell expansion [21, 22] compared to IL-2 only-treated cells. Kaartinen and colleagues have reported that low IL-2 concentrations (0-5 $\mathrm{IU} / \mathrm{mL}$ ) while displaying meager $\mathrm{T}$ cell expansion, favor the less differentiated memory $\mathrm{T}$ cells, while higher concentrations (up to $300 \mathrm{IU} / \mathrm{mL}$ ) produce $\mathrm{T}_{\text {Eff }}$ populations [16]. They also reported that the $\mathrm{T}_{\mathrm{SCM}}$ subset was undetectable regardless of IL-2 concentration. Due to the need for high $\mathrm{T}$ cell numbers in clinical settings, the trials opt to use all $\mathrm{CD}^{+}$populations of $\mathrm{T}$ cells for CAR $\mathrm{T}$ cell or TCR T cell therapy [23-25]. A study in 2002 assessed the expansion of $\mathrm{T}$ cells from four donors while ranging IL-2 concentration from 0.2 to $2000 \mathrm{IU} / \mathrm{mL}$. T cells showed a meager expansion at $0.2-20 \mathrm{IU} / \mathrm{mL}$ IL-2, as they expanded less than 10 folds. At 100-2000 IU/ $\mathrm{mL}, \mathrm{T}$ cells showed significant expansion compared to lower concentrations, but there was no difference 


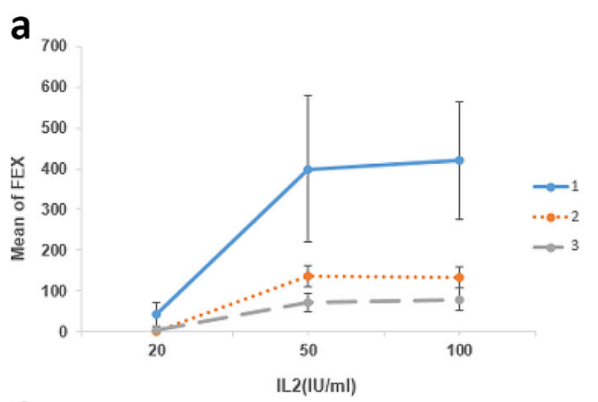

C
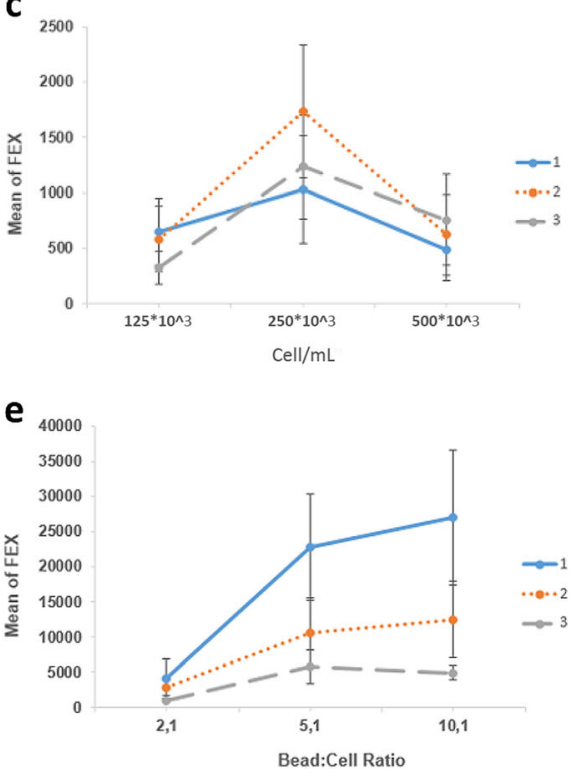

b

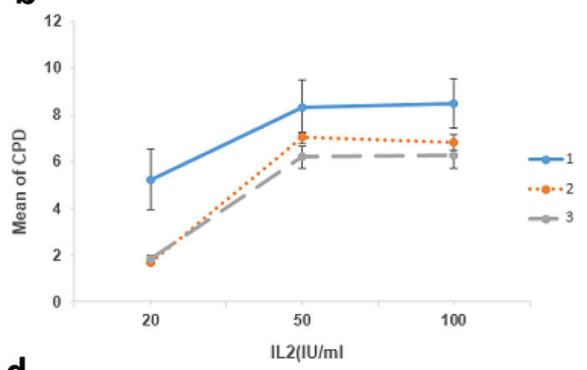

d

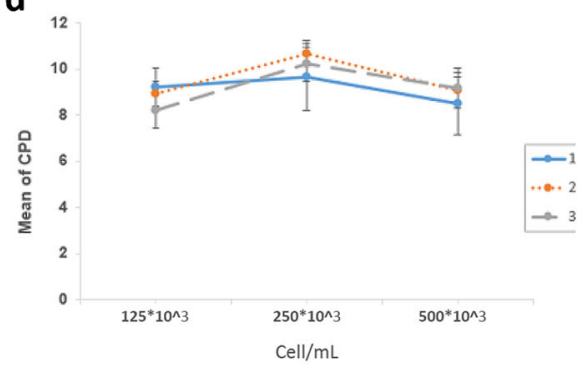

f

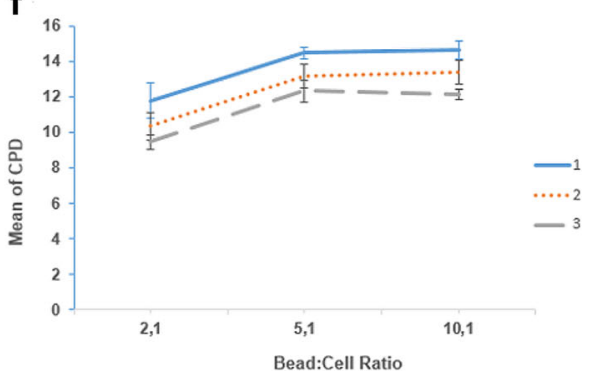

Fig. 5 The fold expansion $(\mathbf{a}, \mathbf{c}, \mathbf{e})$ and CPD $(\mathbf{b}, \mathbf{d}, \mathbf{f})$ results of the three donors on day 28 . Twenty international units per milliliter produced the lowest number of T cells, while the difference between 50 and $100 \mathrm{IU} / \mathrm{mL}$ was not significant $(\mathbf{a}, \mathbf{b})$. All samples experienced peak expansion in $250 \times 10^{3} \mathrm{cell} / \mathrm{mL}(\mathbf{c}, \mathbf{d}) .2: 1 \mathrm{~B}: \mathrm{C}$ ratio results were lower than the other two, and while 10:1 increased expansion more than 5:1, the difference was not significant $(\mathbf{e}, \mathbf{f})$

between these groups [26]. Our results showed a higher expansion rate when increasing the IL-2 concentration from 20 to $50 \mathrm{IU} / \mathrm{mL}$, but no significant difference in expansion rate occurred when IL-2 concentrations were further increased. This can be seen as an advantage, since the use of lower IL-2 concentrations not only reduces the costs of immunotherapies but also reduces negative IL-2 withdrawal effects on $\mathrm{T}$ cells postexpansion, diminishing $\mathrm{T}$ cell exhaustion $[27,28]$. Moreover, in high IL-2 concentrations, endogenous IL-2 secretion is suppressed by Stat- 5 and Blimp- 1 proteins in negative feedback [29]. In a study $\mathrm{T}$ cells from three donors were expanded at three different concentrations of 20,100 , and $1000 \mathrm{IU} / \mathrm{mL}$ of $\mathrm{IL}-2$ for 3 weeks. No

Table 1 Flow cytometry profile of PBMCs (day 0) and T cells (day 28) of the three donors. The results are shown as mean \pm SD

\begin{tabular}{|c|c|c|c|c|c|c|}
\hline & CD3 (\%) & CD4 (\%) & CD8 (\%) & CD3/CD4 (\%) & CD3/CD8 (\%) & CD4/CD8 (\%) \\
\hline \multicolumn{7}{|l|}{ PBMC } \\
\hline Donor 1 & $57 \pm 5.7$ & $31.7 \pm 2.4$ & $26 \pm 2.1$ & $30.9 \pm 6.4$ & $21 \pm 2$ & $1.2 \pm 0.5$ \\
\hline Donor 2 & $56.9 \pm 2.4$ & $30.2 \pm 2.6$ & $26.9 \pm 1.6$ & $27.1 \pm 6.1$ & $24.5 \pm 1.8$ & $1.7 \pm 0.7$ \\
\hline Donor 3 & $56.8 \pm 8.5$ & $28.5 \pm 4.3$ & $27.4 \pm 2.5$ & $26.8 \pm 12.8$ & $25.6 \pm 2.2$ & $1.1 \pm 0.2$ \\
\hline \multicolumn{7}{|c|}{ T cell } \\
\hline Donor 1 & $97.5 \pm 1.8$ & $19.3 \pm 10.5$ & $72.1 \pm 19.4$ & $17.3 \pm 7.3$ & $70.7 \pm 13.4$ & $1.34 \pm 0.4$ \\
\hline Donor 2 & $96.6 \pm 1.9$ & $16.5 \pm 9.9$ & $70.4 \pm 15.8$ & $14.7 \pm 8.7$ & $65.8 \pm 11.5$ & $2.1 \pm 0.3$ \\
\hline Donor 3 & $98 \pm 1.3$ & $20.4 \pm 11.5$ & $69.9 \pm 17.7$ & $16.7 \pm 9.1$ & $68.7 \pm 10.3$ & $1.5 \pm 0.5$ \\
\hline
\end{tabular}


significant difference until day 14 was observed; however, on day 21 , the $100 \mathrm{IU} / \mathrm{mL}$ group showed the highest expansion rate, whereas the $20 \mathrm{IU} / \mathrm{mL}$ group resulted in the least expansion. Interestingly, 20 and $100 \mathrm{IU} / \mathrm{mL}$ concentrations yielded a 98\% CD3 population, while $1000 \mathrm{IU} / \mathrm{mL}$ produced only $66 \% \mathrm{CD} 3+$ cells [30]. In a similar study, Berglund et al. did not find any difference in $\mathrm{T}$ cell expansion over a one-week period when IL-2 ranged from 50 to $600 \mathrm{IU} / \mathrm{mL}$ [19]. Our findings corroborate these studies.

In all cell expansion protocols, seeding density plays an essential role, as it directly affects cell-cell, and in the case of T cell, cell-APC interactions and cytokine exchanges. Based on our findings, too high and too low densities are counterproductive, and equilibrium in cell/ area is key. As we found, for T cell expansion, $250 \times 10^{3}$ cells $/ \mathrm{mL}$ of a 24-well plate is the optimum seeding density. Considering the unique surface area of the wells in a culture plate, the number of wells in each plate may show different results. Ma et al. compared the outcomes of $\mathrm{T}$ cell expansion using $1 \times 10^{6}, 1 \times 10^{5}, 1 \times 10^{4}, 1 \times 10^{3}$ cell $/ \mathrm{mL}$ densities in 6-well culture plates in $2 \mathrm{~mL}$ of medium and concluded that $1 \times 10^{6} \mathrm{cell} / \mathrm{mL}\left(1 \times 10^{7}\right.$ cell $\left./ \mathrm{cm}^{2}\right)$ density produced the best results. The wells in 6-well and 24-well plates have 9.6 and $1.9 \mathrm{~cm}^{2}$ surface area, respectively. This means that $1 \times 10^{7} \mathrm{cell} / \mathrm{cm}^{2}$ in a 6 -well plate is approximately equivalent to $200 \times 10^{4}$ cell $/ \mathrm{cm}^{2}\left(200 \times 10^{3} \mathrm{cell} / \mathrm{mL}\right)$ in a 24 -well plate, which is closest to our results [31].

Anti-CD3/CD28 coated beads can act as artificial APCs, and so, are indispensable for $\mathrm{T}$ cell activation and subsequent expansion. To reveal the optimal B:C ratio with the highest expansion yield, Trickette et al. expanded $\mathrm{T}$ cells of four healthy donors at different $\mathrm{B}: \mathrm{C}$ ratios for 2 weeks. They reported the least expansion in the 1:10 B:C ratio and an increased expansion when increasing the number of beads to $5: 1$ ratio, which was corroborated by our results [26]. In addition, they found that after expansion, the $\mathrm{CD} 4^{+}$population diminished to less than $15 \%$, and $\mathrm{CD}^{+} \mathrm{T}$ cells constituted the majority of cells, which were also in agreement with our results. Shi et al. compared the expansion potential of 1:5, 1:1, and 3:1 B:C ratio over a 1-week period and reported the best expansion rate in the highest ratio, i.e., 3 : 1 ratio, and the least expansion in 1:5 [20]. Moreover, in the 1:5 $\mathrm{B}: \mathrm{C}$ ratio, the $\mathrm{CD}^{+}$population consisted of equal portions of $\mathrm{CD}^{+}$and $\mathrm{CD}^{+}$cells, which could be due to poor cell expansion. When cells are activated, they require time to undergo the growth phases; hence, we opted to expand $\mathrm{T}$ cells for 4 weeks until they reach a plateau phase and compared the results [32]. This is evident in our results when expansion dwindles after 2-3 weeks, which is likely caused by T cells' exhaustion and senescence. Therefore, to prevent ex vivo $\mathrm{T}$ cell exhaustion, most protocols opt to expand $\mathrm{T}$ cells for less than 2 weeks, because $\mathrm{T}$ cells typically lose function after 2 weeks of culture. The function of $\mathrm{T}$ cells could have been evaluated in our study by cytotoxicity assays (e.g. LDH assay) to ensure the production of functional $\mathrm{T}$ cells.

A step-up from small-scale static culture (e.g. culture plates and flasks) to large-scale $\mathrm{T}$ cell expansion would be to use bioreactors to mimic the in vivo environment in which $\mathrm{T}$ cells can rapidly proliferate. Although culture plates and flasks are the most traditional culture systems and are considered the gold standard of $\mathrm{T}$ cell culture, their efficacy is hindered by limited oxygen transfer, waste and lactate buildup, contamination risk, and lack of agitation. Novel, automated systems are seeking to rectify these issues. For instance, gas-permeable bags allow for a closed, sterile system with low media evaporation and efficient gas exchange but little control over culture parameters [33]. Currently, many commercial bioreactors such as G-REX ${ }^{ø}$ systems, a variety of rocking-motion bioreactors, CliniMACS ${ }^{\bullet}$ Prodigy, etc. are created to address the need for large-scale, clinical settings [34].

\section{Conclusion}

The optimized culture conditions of $\mathrm{T}$ cell expansion are elusive since many different factors contribute to its outcome. Notably, T cell stimulation and co-stimulation methods, various cytokines, growth media and sera, oxygen concentration, ambient $\mathrm{pH}$, initial seeding density, and static or dynamic culture are all elements that affect the result of $\mathrm{T}$ cell expansion. Here, we attempted to optimize the most prominent and base $\mathrm{T}$ cell culture conditions in laboratory settings. By comprehensive examination of these parameters, we concluded that $250 \times 10^{3}$ cell $/ \mathrm{mL}, 50 \mathrm{IU} / \mathrm{mL} \mathrm{IL}-2$, and 5:1 B:C ratio for initial activation is the most efficient and ideal condition among these three factors for the expansion of polyclonal $\mathrm{T}$ cells.

\section{Methods \\ PBMC isolation and general $\mathrm{T}$ cell culture}

This study was approved by the National Committee for Ethics in Biomedical Research (IR.TUMS.SPH.REC.1397.050). Peripheral blood was drawn from healthy donors after obtaining written informed consent. Before blood collection, the donors were clinically evaluated by a physician, and a complete blood cell count was conducted (Table 2). All donors were men and within a close range of age. The mononuclear cell portion of the peripheral blood (PBMC) was isolated using a densitygradient separation medium $(1.077 \mathrm{~g} / \mathrm{mL}$, FicollHypaque, GE Healthcare, UK). The cell pellet was seeded in a 24-well culture plate containing $2 \mathrm{~mL}$ TexMACS medium (Miltenyi Biotec, Germany) supplemented with $10 \%$ heat-inactivated FBS (Gibco, USA) or 
Table 2 The baseline demographic and hematological characteristics of the donors

\begin{tabular}{llllll}
\hline Donor & WBC count $\left(\mathbf{1 0}^{\mathbf{3}} / \boldsymbol{\mu l}\right)$ & Lymphocyte count $\left(\mathbf{1 \mathbf { 0 } ^ { 3 }} / \boldsymbol{\mu l}\right)$ & lymphocyte percentage $(\%)$ & Sex & Age $(\mathbf{y e a r})$ \\
\hline 1 & 5.4 & 1.7 & 31.2 & $\mathrm{M}$ & 26 \\
2 & 4.4 & 2.2 & 50.6 & $\mathrm{M}$ & 25 \\
3 & 6.1 & 1.9 & 31.6 & $\mathrm{M}$ & 28 \\
\hline
\end{tabular}

platelet lysate (SABZ, Iran), 1X penicillin/streptomycin (Bioidea, Iran), and recombinant human IL-2 (Miltenyi Biotec, Germany). For T cell expansion and activation, $\mathrm{T}$ Cell Activation/Expansion Kit (Miltenyi Biotec, Germany) containing anti-CD2, -CD3, and -CD28coated MACSiBead ${ }^{\text {TM }}$ particles was used at different B:C ratio depending on the test group, and bead were removed on day 7 using a MACSiMAG ${ }^{\mathrm{TM}}$ Separator to prevent autofluorescence and $\mathrm{T}$ cell over-activation.

\section{Study grouping}

The following groups were selected based on previously published literature and expansion studies in our research laboratory $[6,8]$. At first, five groups in which IL2 concentration was the variable were assigned to optimize IL-2 concentration. Secondly, six varying seeding density groups were appointed to discern the highest expansion rate of cell density. Lastly, seven groups of B: $\mathrm{C}$ ratio were selected after the result of the previous two experiments.

\section{IL-2 concentration comparative groups}

To assess the effect of IL-2 concentration on T cell expansion, PBMCs were seeded at a standard concentration of $1 \times 10^{6}$ cells $/ \mathrm{mL}$ in a 24-well culture plate, and were then stimulated once with microbeads at $1: 2 \mathrm{~B}: \mathrm{C}$ ratio, followed by expansion using five different IL-2 concentrations $(20,50,100,200,500 \mathrm{IU} / \mathrm{mL})$.

\section{Seeding density comparative groups}

To assess the effect of seeding density on T cell expansion, PBMCs were seeded at $62 \times 10^{3}, 125 \times 10^{3}, 250 \times$ $10^{3}, 500 \times 10^{3}, 1 \times 10^{6}$, and $1.5 \times 10^{6} \mathrm{cell} / \mathrm{mL}$, and then were stimulated once with microbeads at $1: 2 \mathrm{~B}: \mathrm{C}$ ratio, followed by expansion using $50 \mathrm{IU} / \mathrm{mL}$ IL-2 which was selected based on the results from IL-2 concentration comparative groups.

\section{$B: C$ ratio comparative groups}

To assess the effect of $\mathrm{B}: \mathrm{C}$ ratio on $\mathrm{T}$ cell expansion, PBMCs were seeded at a concentration of $250 \times 10^{3}$ cells/mL in a 24-well culture plate (based on the results of seeding density comparative groups), and were then stimulated once with microbeads at different $\mathrm{B}: \mathrm{C}$ ratios (1:10, 1:5, 1:2, 1:1, 2:1, 5:1, and 10:1), followed by expansion using $50 \mathrm{IU} / \mathrm{mL}$ IL-2 (based on IL-2 concentration comparative groups).

\section{Monitoring T cell proliferation}

Throughout the culture process, the cells were counted at nine time points (i.e., days $0,6,8,11,14,17,21,25$, and 28), and cell number was determined via trypan blue exclusion dye. The kinetics of $\mathrm{T}$ cell expansion was assessed under different culture conditions by calculating the cumulative population doubling (CPD) and fold expansion. We determined fold expansion by dividing the final cell count by the initial cell number. Population doubling (PD) was calculated using the equation: $\mathrm{PD}=$ $3.32(\log \mathrm{N} 1-\log \mathrm{N} 0)$, where N0 represents the number of initially seeded cells and N1 represents the number of harvested cells at each time-point, respectively. After counting the cells, a number of cells equal to the initial seeding density of their respective group were subcultured to a new well. The cells were cultured at $37^{\circ} \mathrm{C}$ in a humidified atmosphere containing $5 \% \mathrm{CO}_{2}$ for 28 days. In all the experiments, 24-well culture plates containing $2 \mathrm{~mL}$ of cell and culture media mixture were used. Every 3 days, half the culture medium was replaced with a fresh medium containing the same concentration of IL2.

\section{Comparison of $\mathrm{T}$ cell expansion of three donors in optimal and near-optimal conditions}

After determining the best culture condition for the greatest yield of $\mathrm{T}$ cell in one donor, in each study group, PBMCs of three different donors, one of whom was the first donor, were expanded and compared in that condition to one level higher and one level lower. In other words, the PBMCs of the donors were seeded at $1 \times 10^{6} \mathrm{cell} / \mathrm{mL}$, stimulated with beads at 1:2 B:C ratio, and expanded using 20, 50, and 100 $\mathrm{IU} / \mathrm{mL}$ IL-2. In the next experiment, the PBMCs of the donors were seeded at $125 \times 10^{3}, 250 \times 10^{3}$, and $500 \times 10^{3}$ cell $/ \mathrm{mL}$, stimulated with beads at $1: 2 \mathrm{~B}: \mathrm{C}$ ratio, and expanded using $50 \mathrm{IU} / \mathrm{mL}$ IL-2. Lastly, PBMCs of the three donors were seeded at $250 \times 10^{3}$ cell/mL, stimulated with beads at $2: 1,5: 1$, and 10:1 B: $\mathrm{C}$ ratio, and expanded using $50 \mathrm{IU} / \mathrm{mL}$ IL-2 (Fig. 6).

\section{Flow cytometry analysis}

Immunophenotyping was performed on PBMCs before expansion and $\mathrm{T}$ cells on day 28. Cells were washed in complete medium, and $2 \times 10^{5}$ cells were re-suspended in the $100 \mu \mathrm{l}$ PBS containing 3\% Bovine Serum Albumin (Sigma, USA). Then. The cells were incubated with $5 \mu \mathrm{l}$ 


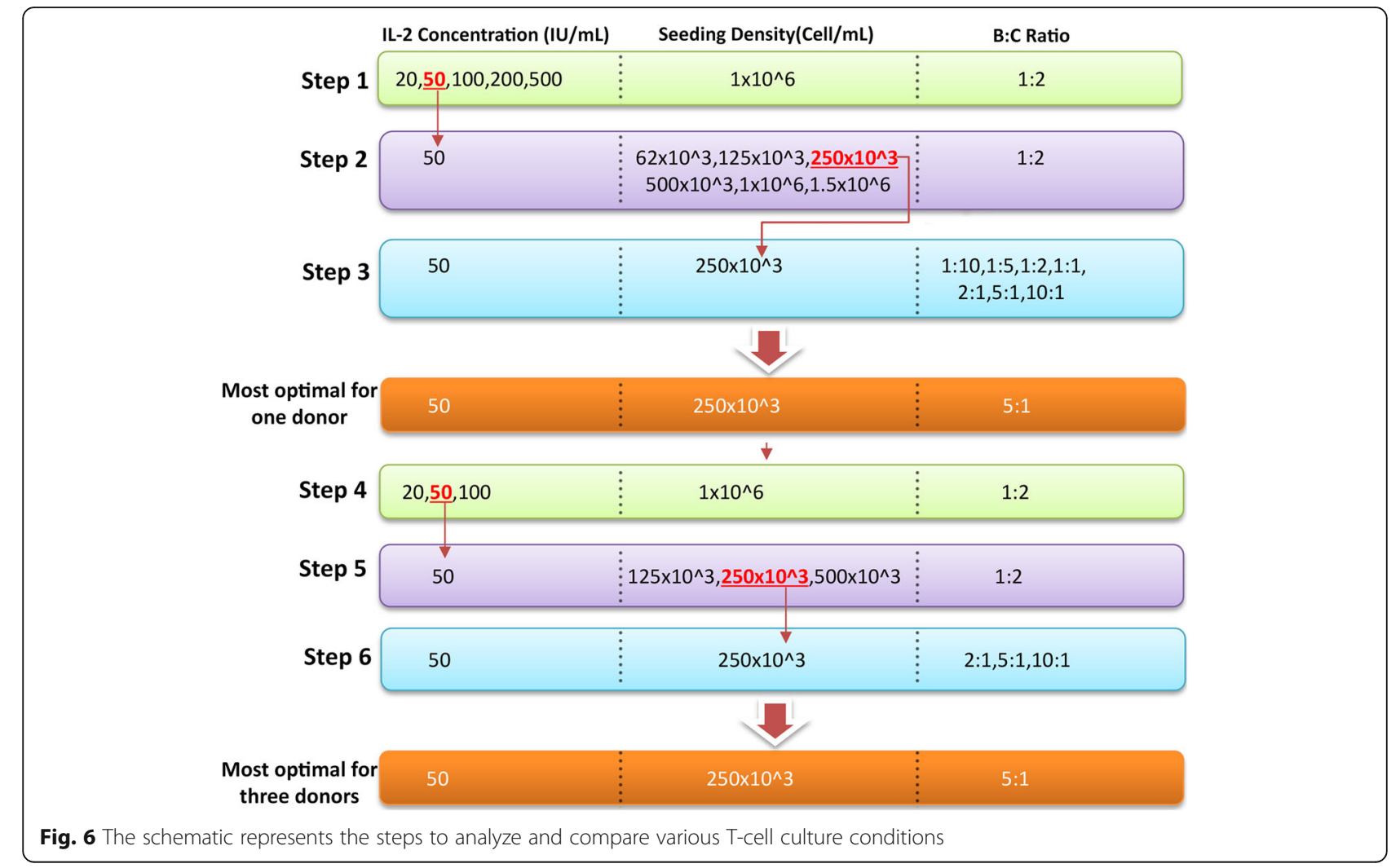

of Anti-Human CD3-PerCP (Miltenyi Biotec, Germany), Anti-Human CD4-FITC/CD8-PE (BD Biosciences, USA), Mouse IgG2a Isotype PerCP (Miltenyi Biotec, Germany), Mouse IgG1 Isotype-FITC (BD Biosciences, USA), and Mouse IgG1 Isotype-PE Biosciences, USA) at $4{ }^{\circ} \mathrm{C}$ in the dark. Cells were analyzed with BD FACSCalibur $^{\text {ras }}$ Flowcytometer (BD Biosciences, USA) for cell surface markers and the data was processed using FlowJo software version X (FlowJo LLC, USA).

\section{Statistical analysis}

The difference between cell expansion results was analyzed by Two-Way Repeated Measures ANOVA followed by Tukey post hoc test using GraphPad Prism version 8 for Windows. All the experiments were performed independently in triplicates. $P$-values less than 0.05 were considered statistically significant.

\section{Acknowledgments}

The authors acknowledge the help and funding of Tehran University of Medical Sciences for conducting this study.

\section{Adherence to guidelines}

The authors confirm that all methods were carried out in accordance with relevant guidelines and regulations.

\section{Authors' contributions}

All authors contributed to the study conception and design. The author(s) read and approved the final manuscript.
Funding

The research leading to these results received funding from Tehran University of Medical Sciences under Grant Agreement No 954386.

\section{Availability of data and materials}

The datasets used and/or analyzed during the current study are available from the corresponding author on reasonable request.

\section{Declarations}

Ethics approval and consent to participate

This study was approved by the National Committee for Ethics in Biomedical Research (IR.TUMS.SPH.REC.1397.050). Informed consent was obtained from all individual participants included in the study.

\section{Consent for publication}

Written informed consent for publication of their clinical details and/or clinical images were obtained from the patient/parent/guardian/ relative of the patient. A copy of the consent form is available for review by the Editor of this journal.

\section{Competing interests}

The authors have no relevant financial or non-financial interests to disclose.

\section{Author details}

'Gene Therapy Research Center, Digestive Disease Research Institute, Tehran University of Medical Sciences, Tehran, Iran. ${ }^{2}$ Department of Hematology, School of Allied Medical Sciences, Tehran University of Medical Sciences, Tehran, Iran. ${ }^{3}$ Department of Immunology, School of Medicine, Tehran University of Medical Sciences, Tehran, Iran. 
Received: 24 January 2021 Accepted: 21 June 2021

Published online: 03 July 2021

\section{References}

1. Zhang $\mathrm{H}$, Chen J. Current status and future directions of cancer immunotherapy. J Cancer. 2018;9:1773-81.

2. Emens LA, Ascierto PA, Darcy PK, Demaria S, Eggermont AMM, Redmond $W L$, et al. Cancer immunotherapy: Opportunities and challenges in the rapidly evolving clinical landscape. Eur J Cancer. 2017:81:116-29.

3. McBride DA, Kerr MD, Wai SL, Shah NJ. Applications of molecular engineering in T-cell-based immunotherapies. Wiley Interdiscip Rev Nanomedicine Nanobiotechnology. 2019;11:e1557.

4. Met Ö, Jensen KM, Chamberlain CA, Donia M, Svane IM. Principles of adoptive T cell therapy in cancer. Semin Immunopathol. 2019;41:49-58.

5. Holzinger A, Barden $M$, Abken $H$. The growing world of CAR T cell trials: a systematic review. Cancer Immunol. Immunother. 2016;65:1433-50.

6. Kiani J, Naderi M, Torabi-Rahvar M, Ranjbar A, Aghayan H-R, Ehsan Janzamin NA. Generation of CD19-Targeted Chimeric Antigen Receptor T Cells. Arch Iran Med. 2019;22:7-10.

7. Liu X, Zhao Y. CRISPR/Cas9 genome editing: Fueling the revolution in cancer immunotherapy. Curr Res Transl Med. 2018;66:39-42.

8. Ghaffari S, Torabi-Rahvar M, Omidkhoda A, Ahmadbeigi N. Impact of various culture conditions on ex vivo expansion of polyclonal T cells for adoptive immunotherapy. APMIS. 2019;127(12):737-45. https://doi.org/10.1111/a pm.12981.

9. Kim JV, Latouche J-B, Rivière I, Sadelain M. The ABCs of artificial antigen presentation. Nat Biotechnol. 2004;22(4):403-10. Available from: http://www. nature.com/articles/nbt955. https://doi.org/10.1038/nbt955.

10. Appleman $L$, Boussiotis VA. T cell anergy and costimulation. Immunol Rev. 2003;192(1):161-80. Available from: http://doi.wiley.com/10.1034/j.1600065X.2003.00009.X

11. Kim DS, Lee MW, Ko YJ, Chun YH, Kim HJ, Sung KW, et al. Cell culture density affects the proliferation activity of human adipose tissue stem cells. Cell Biochem Funct. 2016;34(1):16-24. https://doi.org/10.1002/cbf.3158.

12. Cha KJ, Kong S-Y, Lee JS, Kim HW, Shin J-Y, La M, et al. Cell densitydependent differential proliferation of neural stem cells on omnidirectional nanopore-arrayed surface. Sci Rep. 2017:7:13077 Available from: http://www. nature.com/articles/s41598-017-13372-6

13. Zhou H, Weir MD, Xu HHK. Effect of cell seeding density on proliferation and Osteodifferentiation of umbilical cord stem cells on calcium phosphate cement-fiber scaffold. Tissue Eng Part A. 2011;17(21-22):2603-13. Available from: https://www.liebertpub.com/doi/10.1089/ten.tea.2011.0048.

14. Heng BC, Bezerra PP, Preiser PR, Alex Law SK, Xia Y, Boey F, et al. Effect of cell-seeding density on the proliferation and gene expression profile of human umbilical vein endothelial cells within ex vivo culture. Cytotherapy. 2011;13(5):606-17. Available from: https://linkinghub.elsevier.com/retrieve/ pii/S1465324911705412. https://doi.org/10.3109/14653249.2010.542455.

15. Ross SH, Cantrell DA. Signaling and function of Interleukin-2 in T Iymphocytes. Annu Rev Immunol. 2018;36(1):411-33. https://doi.org/10.114 6/annurev-immunol-042617-053352.

16. Luostarinen A, Kaartinen T, Maliniemi P, Keto J, Arvas M, Belt H, et al. Low IL2 concentration favors generation of early memory $T$ cells over terminal effectors during CAR T-cell expansion. Cytotherapy. 2017;19:689-702 Available from: https://linkinghub.elsevier.com/retrieve/pii/S14653249173 05212.

17. Rohaan MW, Wilgenhof S, Haanen JBAG. Adoptive cellular therapies: the current landscape. Virchows Arch. 2019;474:449-61.

18. Abramowski-Mock U, Delhove JM, Qasim W. Gene Modified T Cell Therapies for Hematological Malignancies. Hematol Oncol Clin North Am. 2017;31: 913-926.

19. Berglund S, Gertow J, Magalhaes I, Mattsson J, Uhlin M. Cord Blood T Cells Cultured With IL-7 in Addition to IL-2 Exhibit a Higher Degree of Polyfunctionality and Superior Proliferation Potential. J Immunother. 2013; 36:432-41 Available from: http://content.wkhealth.com/linkback/ openurl?sid=WKPTLP:landingpage\&an=00002371-201310000-00005.

20. Shi Y, Wu W, Wan T, Liu Y, Peng G, Chen Z, et al. Impact of polyclonal antiCD3/CD28-coated magnetic bead expansion methods on $T$ cell proliferation, differentiation and function. Int Immunopharmacol. 2013;15: 129-37 Available from: https://linkinghub.elsevier.com/retrieve/pii/S1 567576912003153
21. Xu Y, Zhang M, Ramos CA, Durett A, Liu E, Dakhova O, et al. Closely related T-memory stem cells correlate with in vivo expansion of CAR.CD19-T cells and are preserved by IL-7 and IL-15. Blood. 2014;123:3750-9.

22. Zhou J, Jin L, Wang F, Zhang Y, Liu B, Zhao T. Chimeric antigen receptor T (CAR-T) cells expanded with IL-7//L-15 mediate superior antitumor effects. Protein Cell. 2019;10:764-9.

23. Lu Y, Xue J, Deng T, Zhou X, Yu K, Deng L, et al. Safety and feasibility of CRISPR-edited T cells in patients with refractory non-small-cell lung cancer. Nat Med. 2020;26(5):732-40. https://doi.org/10.1038/s41591-020-0840-5.

24. Stadtmauer EA, Fraietta JA, Davis MM, Cohen AD, Weber KL, Lancaster E, et al. CRISPR-engineered T cells in patients with refractory cancer. Science (80- ). 2020:367

25. Fry TJ, Shah NN, Orentas RJ, Stetler-Stevenson M, Yuan CM, Ramakrishna S, et al. CD22-targeted CAR T cells induce remission in B-ALL that is naive or resistant to CD19-targeted CAR immunotherapy. Nat Med. 2018:24(1):20-8. https://doi.org/10.1038/nm.4441.

26. Trickett AE, Kwan YL, Cameron B, Dwyer JM. Ex vivo expansion of functional T lymphocytes from HIV-infected individuals. J Immunol Methods. 2002;262: 71-83 Available from: http://linkinghub.elsevier.com/retrieve/pii/S00221 75902000182.

27. Hay AE, Cheung MC. CAR T-cells: costs, comparisons, and commentary. J Med Econ. 2019:22:613-5.

28. Arabi F, Torabi-Rahvar M, Shariati A, Ahmadbeigi N, Naderi M. Antigenic targets of CAR T Cell Therapy. A retrospective view on clinical trials. Exp Cell Res. 2018;369:1-10 Available from: https://linkinghub.elsevier.com/retrieve/ pii/S0014482718302702

29. Villarino AV, Tato CM, Stumhofer JS, Yao Z, Cui YK, Hennighausen L, et al. Helper T cell IL-2 production is limited by negative feedback and STATdependent cytokine signals. J Exp Med. 2007;204(1):65-71. https://doi.org/1 0.1084/jem.20061198.

30. Martkamchan S, Onlamoon N, Wang S, Pattanapanyasat K, Ammaranond P. The Effects of Anti-CD3/CD28 Coated Beads and IL-2 on Expanded T Cell for Immunotherapy. Adv Clin Exp Med. 2016;25:821-8 Available from: http:// www.advances.umed.wroc.pl/en/article/2016/25/5/821/.

31. Ma Q, Wang Y, Lo ASY, Gomes EM, Junghans RP. Cell density plays a critical role in ex vivo expansion of T cells for adoptive immunotherapy. J Biomed Biotechnol. 2010;2010:1-13. https://doi.org/10.1155/2010/386545.

32. Alenzi FQB. Links between apoptosis, proliferation and the cell cycle. Br J Biomed Sci. 2004;61:99-102 Available from: https://www.tandfonline.com/ doi/full/10.1080/09674845.2004.11732652

33. Swiech K. Kelen Cristina Ribeiro Malmegrim VP-C. Chimeric Antigen Receptor T Cells. 2019; Available from: https://www.springer.com/gp/book/ 9781071601457

34. Baudequin T, Robin Nyland HY. Objectives, benefits and challenges of bioreactor systems for the clinical-scale expansion of T lymphocyte cells. Biotechnol Adv. 2021;49:107735. https://doi.org/10.1016/j.biotechadv.2021.1 07735 .

\section{Publisher's Note}

Springer Nature remains neutral with regard to jurisdictional claims in published maps and institutional affiliations.

Ready to submit your research? Choose BMC and benefit from:

- fast, convenient online submission

- thorough peer review by experienced researchers in your field

- rapid publication on acceptance

- support for research data, including large and complex data types

- gold Open Access which fosters wider collaboration and increased citations

- maximum visibility for your research: over $100 \mathrm{M}$ website views per year

At $\mathrm{BMC}$, research is always in progress.

Learn more biomedcentral.com/submissions 